

Privacy's Blueprint 



\section{Privacy's Blueprint}

\section{The Battle to Control the Design of New Technologies}


Copyright $\odot 2018$ by the President and Fellows of Harvard College All rights reserved

Printed in the United States of America

Many of the designations used by manufacturers, sellers, and internet software applications and services to distinguish their products are claimed as trademarks. Where those designations appear in this book and Harvard University Press was aware of a trademark claim, the designations have been printed in initial capital letters.

First printing

Library of Congress Cataloging-in-Publication Data

Names: Hartzog, Woodrow, 1978- author.

Title: Privacy's blueprint : the battle to control the design of new technologies / Woodrow Hartzog.

Description: Cambridge, Massachusetts : Harvard University Press, 2018. | Includes bibliographical references and index.

Identifiers: LCCN 2017039954 | ISBN 9780674976009 (hardcover : alk. paper)

Subjects: LCSH: Privacy, Right of-United States. | Design and technologyUnited States. | Data protection-Law and legislation-United States.

Classification: LCC KF1262 .H37 2018 | DDC 342.7308/58-dc23

LC record available at https://lccn.loc.gov/2017039954

Jacket design: Jill Breitbarth

Jacket art: Thinkstock/Getty Images 
For Jen, Will, and Romy, with love and gratitude 
